\title{
Estrutura e desenvolvimento dos tricomas secretores em folhas de Piper regnellii(Miq.) C. DC. var. regnellii (Piperaceae) ${ }^{1}$
}

\author{
ELAINE MARIA J. SILVA ${ }^{1}$ e SILVIA RODRIGUES MACHADO²
}

(recebido em 12/02/97; aceito em 16/11/98)

\begin{abstract}
Structure and development of the secretory trichomes in leaves of Piper regnellii (Miq.) C. DC. var. regnellii (Piperaceae)). Piper regnellii has two types of trichomes: pearl glands and sac-like trichomes. Both secretory trichomes originate from the protoderm of the leaf primordium and reach maturity in the young leaves found in the shoot apex. The pearl glands are more abundant on the abaxial surface, while the sac-like trichomes cover completely both young leaf blade. The density of both trichomes decreases during blade expansion, being scarce in the adult leaf. The pearl glands are composed of a basal cell and an apical cell whose shape ranges from semi-globular to spatula-like. Secretion release occurs after rupture of the distended cuticle. The sac-like trichomes are composed of a basal cell, 1-2 stalked cells and an apical conical cell parallel to the leaf surface. The secretion is accumulated in minute subcuticular spaces. No cuticular ruptures have been observed.
\end{abstract}

RESUMO - (Estrutura e desenvolvimento dos tricomas secretores em folhas de Piper regnellii (Miq.) C. DC. var. regnellii (Piperaceae)). Nesta espécie ocorrem dois tipos de tricomas secretores: glândula perolada e tricoma saculiforme. Ambos originam-se na protoderme do primórdio foliar e atingem sua maturidade nas folhas jovens presentes no ápice caulinar. A densidade dos dois tipos de tricomas diminui durante a expansão do limbo, sendo raros na folha adulta. As glândulas peroladas são constituídas por uma célula basal e por uma célula apical grande cuja forma varia de semi-globóide a espatulada. A liberação da secreção ocorre após a ruptura da cutícula distendida. Os tricomas saculiformes são constituídos por uma célula basal, 1-2 células colares e uma célula apical cônica, de posição inclinada à superfície foliar. A secreção acumula-se em espaços subcuticulares diminutos, não tendo sido observada ruptura da cutícula.

Key words - Piperaceae, Piper regnellii, ontogeny, glandular trichomes, secretion

\section{Introdução}

O gênero Piper L. inclui um grande número de espécies que se caracterizam pela produção de óleos essenciais de grande interesse nas indústrias farmacêutica e de inseticidas (Alencar et al.1971, Maia et al. 1992, Machado et al.1994). Embora as plantas deste gênero sejam relativamente bem estudadas sob o aspecto farmacológico é raro encontrar na literatura associação entre a presença de substâncias ativas e as estruturas vegetais que as produzem. $\mathrm{O}$ extrato foliar de Piper regnellii (Miq.) C. DC. var. regnellii, espécie popularmente utilizada no tratamento da dor, afecções febris e/ou reumáticas, apresenta atividade analgésica positiva (Di Stasi 1987). Salatino \& Silva (1975) afirmam que o óleo essencial existente nas folhas de $P$. regnellii encontra-se em idioblastos e sob a forma de gotículas no mesofilo, não se referindo aos tricomas secretores, comuns na família Piperaceae. De acordo com Solereder (1908) e Metcalfe \& Chalk (1950) estes tricomas são de dois tipos: pequenas glândulas consti-

1. Parte da tese de doutorado de E.M.J. Silva. Apoio FAPESP e FUNDUNESP.

2. Departamento de Botânica, Instituto de Biociências, Universidade Estadual Paulista, Caixa Postal 501, 18618 Botucatu, SP, Brasil. tuídas de uma célula esférica ampla de aspecto reluzente (pearl glands) e tricomas constituídos de pedicelo e célula apical esférica, hemi-esférica ou saculiforme (sac-like). Considerando a escassez de informações sobre as estruturas secretoras em espécies de Piperaceae com potencial medicinal, este trabalho descreve a estrutura e o desenvolvimento dos tricomas secretores presentes nas folhas de Piper regnellii var. regnellii.

\section{Material e métodos}

Amostras de ápices vegetativos e folhas em diferentes fases do desenvolvimento foram coletadas de plantas adultas de Piper regnellii (Miq.) C. DC. var. regnellii (Piperaceae), estabelecidas em canteiros experimentais do Departamento de Botânica, Instituto de Biociências - Campus de Botucatu - UNESP, e preparadas para análises em microscopia de luz e microscopia eletrônica de varredura (MEV). As exsicatas do material estão depositadas no Herbário Botu, sob o número 15567.

Para a análise em microscopia de luz, o material foi fixado em solução de Karnovsky (Karnovsky 1965), desidratado em série etílica e infiltrado em resina glicol-metacrilato. As seções de 5-8 $\mu \mathrm{m}$ obtidas em micrótomo rotativo foram coradas com azul de toluidina $0,05 \%$, em tampão acetato, $\mathrm{pH} 4,7$ (O’ Brien et al. 1964).

A secreção presente no interior das células, bem como, aquela observada na superfície dos tricomas em seções de material fresco, realizadas à mão livre, foram testadas com corantes e reagentes específicos. A presença de polissacarídeos foi detectada com vermelho de rutênio (Johansen 1940); proteína, com solução saturada de ácido pícrico (Johansen 1940); lipídios, com sudan IV (Jensen 1962) e substâncias fenólicas, com solução de cloreto férrico (Johansen 1940). 
Para a análise em microscopia eletrônica de varredura, amostras do terço mediano de folhas em vários estágios do desenvolvimento, bem como, de ápices vegetativos, previamente dissecados e secionados longitudinalmente em dois, foram fixadas em glutaraldeído 2,5\%, tampão fosfato $0,1 \mathrm{M}, \mathrm{pH} 7,3$, desidratadas em série alcoólica e submetidas ao ponto crítico, utilizando-se $\mathrm{CO}_{2}$ como líquido de transição (Robards 1978). Posteriormente, foram recobertas com carbono e ouro $(20 \mathrm{~nm})$ e analisadas ao microscópio eletrônico de varredura Philips SEM-515.

\section{Resultados}

Nas folhas de $P$. regnellii foram observados dois tipos de tricomas secretores: glândula perolada e tricoma saculiforme .

As glândulas peroladas ocorrem isoladas ou agrupadas (figura 1), em ambas as faces do limbo foliar, sendo mais abundantes na face abaxial das folhas em desenvolvimento, presentes no ápice vegetativo (figuras 2 e 3). São raras ou ausentes nas folhas adultas, uma vez que sofrem abscisão durante a expansão do limbo. Na folha adulta, observam-se as cicatrizes (figura 1, seta) destas glândulas circundadas por células epidérmicas dispostas em roseta. Eventualmente, glândulas reluzentes são abundantes nas folhas adultas, podendo atingir até $1 \mathrm{~mm}$ de diâmetro. Quando não sofrem abscisão ou não são retiradas por formigas, murcham progressivamente e perdem o aspecto reluzente, tornando-se de coloração parda.

As glândulas peroladas são tricomas secretores bicelulares, constituídos por uma célula basal e por uma célula apical grande, de forma semi-globóide à espatulada, com cutícula espessa, de superfície ondulada (figura 1) e parede péctico-celulósica delgada.

Durante o processo de secreção, o material acumula-se entre a parede e a cutícula da célula apical, levando à distensão da cutícula e à formação de um espaço conspícuo. Com o acúmulo progressivo da secreção, a cutícula se rompe e libera a secreção mucilaginosa translúcida, que recobre a superfície das estruturas foliares em desenvolvimento presentes no ápice vegetativo (figuras $3 \mathrm{~A}-\mathrm{C}$ e 4 ).
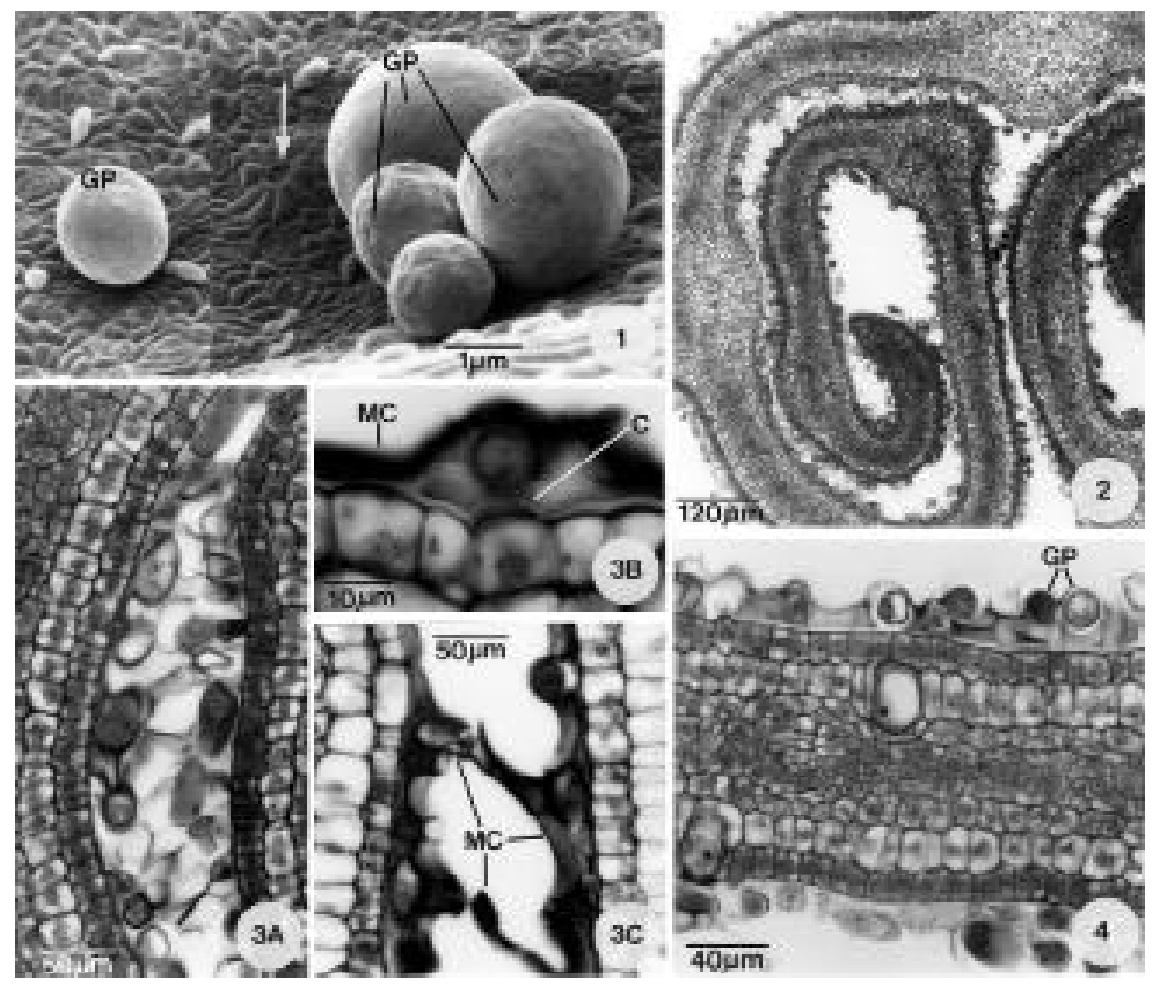

Figuras 1-4. Tricomas secretores em P. regnellii var. regnellii. 1.Vista frontal, em microscopia eletrônica de varredura, da face abaxial do limbo foliar expandido mostrando glândulas peroladas (GP) isoladas ou agrupadas. A seta indica cicatriz da glândula perolada. 2. Limbo foliar em desenvolvimento no interior da estípula, mostrando abundância de tricomas secretores em ambas as faces. 3A-C. Detalhes da figura 2. 3A. Tricomas secretores em diferentes fases de diferenciação na protoderme do limbo foliar. 3B. Glândula perolada (GP) totalmente recoberta por mucilagem (MC). Cutícula espessa (C) na base da célula apical da glândula perolada. 3C. Mucilagem (MC) entre as superfícies do limbo foliar em desenvolvimento. 4. Região distendida do limbo foliar mostrando glândulas peroladas (GP) em processo de abscisão. 
A glândula perolada origina-se precocemente na protoderme do primórdio foliar. A célula precursora (figura 5) é maior que as adjacentes, com citoplasma mais denso e com vacúolos escassos e pequenos, concentrados nos pólos basal e distal da célula. O núcleo é esférico, com nucléolo evidente e ocupa a posição central da célula. Inicialmente, esta célula aumenta de volume, tornando-se papiliforme (figura 6). A seguir, sofre uma divisão transversal originando uma estrutura bicelular, constituída por uma célula basal e outra apical esférica; ambas mostram citoplasma denso, poucos vacúolos, núcleo esférico e central, com nucléolo evidente (figuras 7 e 8). A célula basal mantém-se com características semelhantes às demais células epidérmicas, enquanto que a célula apical continua aumentando de volume, sofre progressiva deposição de material parietal em seu pólo basal, tornando-se semiglobóide (figura 8) a espatulada (figuras 9 e 10). Nesta fase, a célula apical mostra citoplasma denso, núcleo esférico e deslocado para a periferia e coalescência de vacúolos (figura 10). A partir desta fase, tem início a formação do espaço subcuticular.
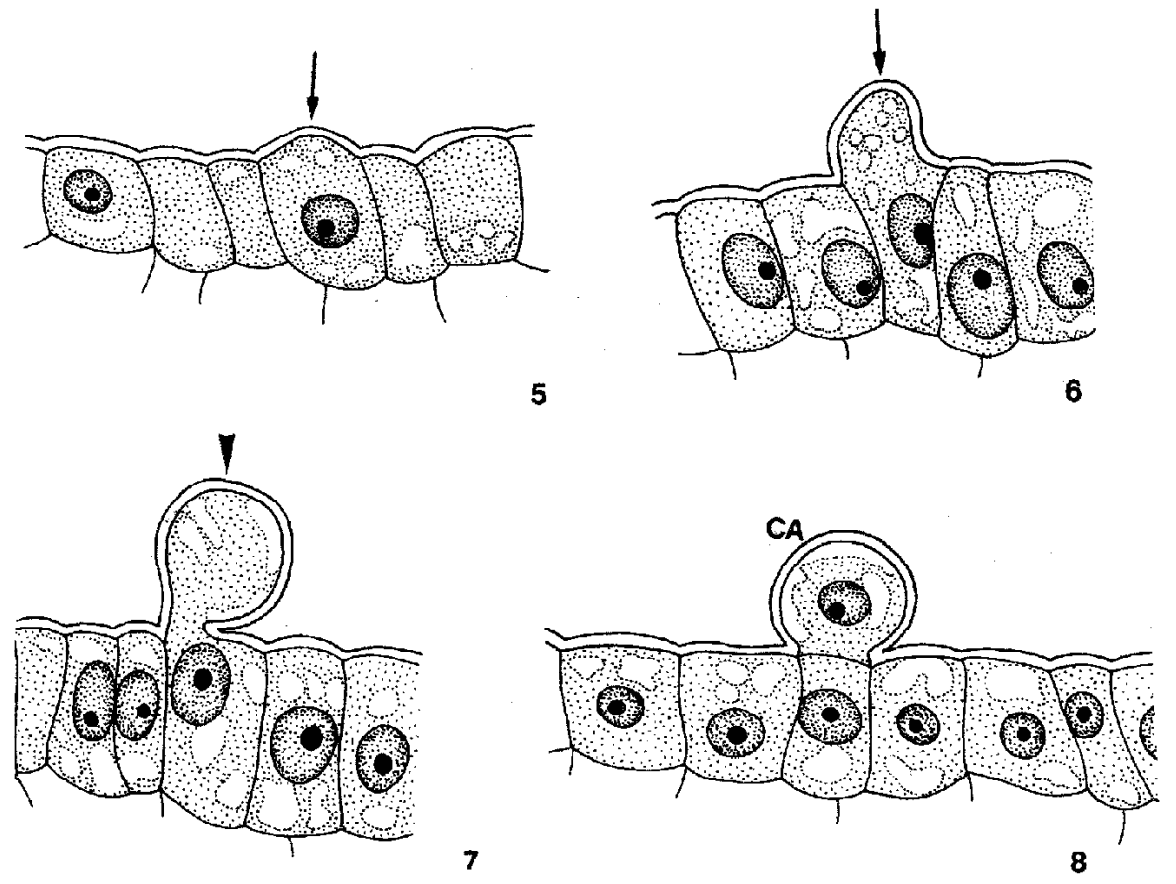

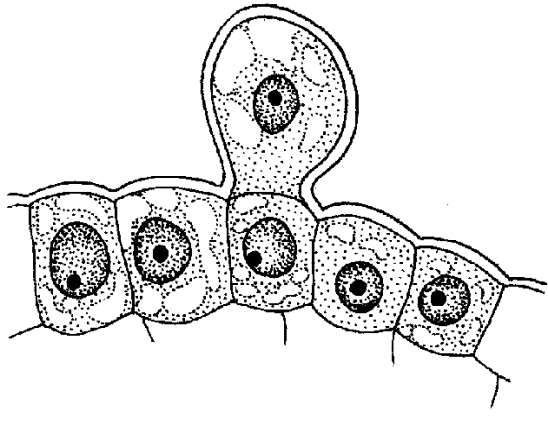

9

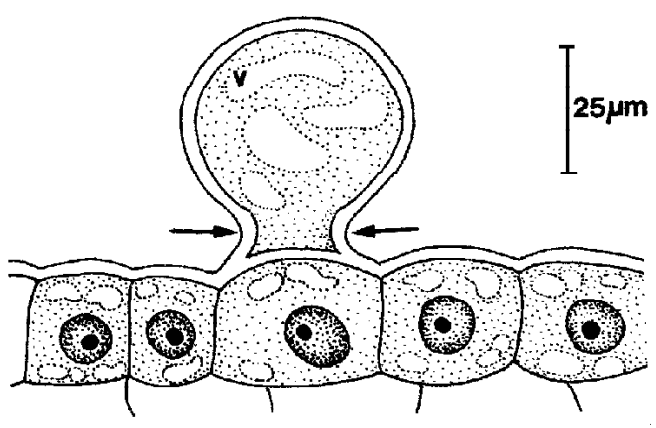

10

Figuras 5-10. Etapas sucessivas do desenvolvimento das glândulas peroladas de P. regnellii var. regnellii. 5. Célula precursora (seta) mostrando citoplasma denso, pequenos vacúolos e núcleo na posição central. 6. Célula precursora papiliforme (seta). 7. Célula precursora (ponta de seta) em divisão transversal. 8. Glândula perolada jovem com célula apical (CA) esférica; notar que ambas as células têm citoplasma denso, pequenos vacúolos e núcleo na posição central. 9. Célula apical semi-globóide. 10. Célula apical espatulada mostrando vacúolos $(\mathrm{V})$ e espessamento das paredes tangenciais externas e internas (setas). 
Os tricomas saculiformes recobrem toda a extensão das folhas jovens (figuras 11 e 12), formando uma cobertura densa em ambas as faces do limbo. À medida que o limbo se expande, a densidade diminui e os tricomas apresentam sinais de senescência, não sofrendo, contudo, abscisão (figuras 13 e 14). São tricomas unisseriados, pluricelulares, constituídos de 3-4 células, sendo uma célula basal, 1-2 células colares e uma célula apical alongada, de posição ligeiramente inclinada em relação à superfície foliar, parecendo-se com um saco cônico e/ou uma biruta (figuras 12 e 13). A célula colar deste tricoma apresenta paredes tangenciais impregnadas de substância graxa, evidenciada com sudan IV. A secreção se acumula temporariamente em pequenos espaços formados pela ligeira distensão da cutícula da célula apical, não sendo observada ruptura da mesma.
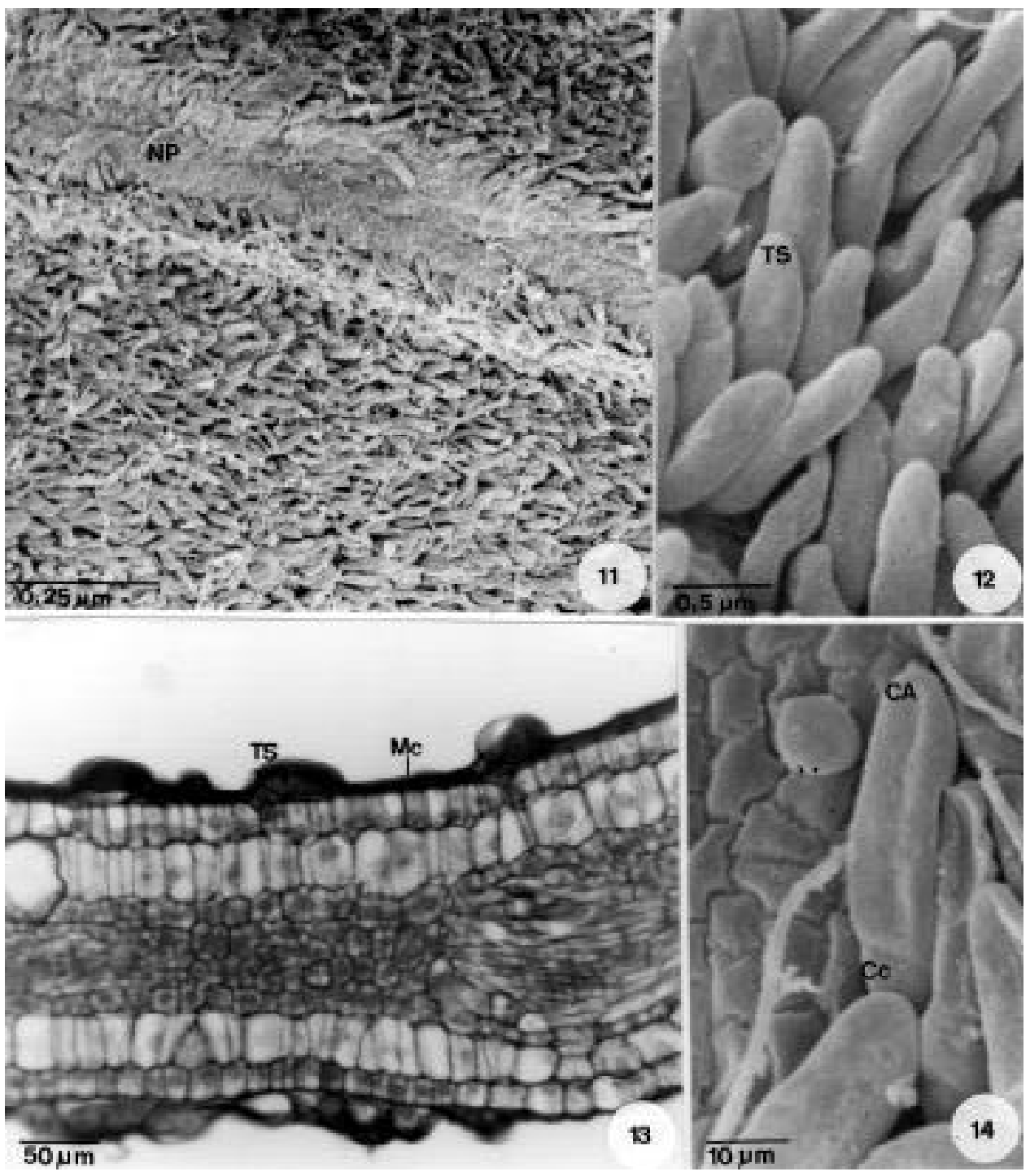

Figuras 11-14. Aspecto geral dos tricomas saculiformes de P. regnellii var. regnellii. 11. Vista frontal, em microscopia eletrônica de varredura, da face abaxial da epiderme foliar, mostrando que estes tricomas formam uma densa cobertura, exceto sobre a nervura principal (NP). 12. Detalhe da figura 11 mostrando tricomas saculiformes (TS). 13. Seção transversal do limbo foliar em desenvolvimento mostrando tricomas saculiformes (TS) recobertos por mucilagem (Mc). Notar célula apical cônica de posição inclinada em relação à superfície foliar. 14. Tricoma saculiforme mostrando célula apical $(\mathrm{CA})$ e célula colar $(\mathrm{Cc})$. 
O tricoma saculiforme origina-se na protoderme do primórdio foliar. A célula precursora deste tricoma é maior e papiliforme, cuja projeção é ligeiramente descentralizada; apresenta citoplasma denso e núcleo esférico de posição central (figura 15, seta). Inicialmente, esta célula aumenta de volume e a seguir, sofre uma divisão transversal originando uma estrutura bicelular representada por uma célula basal e uma célula apical cônica (figura 15, ponta de seta), de posição inclinada em relação à superfície foliar. Nesta fase, ambas as células apresentam citoplasma denso e núcleo esférico, de posição central, com nucléolo evidente (figura 15); a célula apical sofre progressivo alongamento e o núcleo passa a ocupar o terço distal da célula (figura 16). A seguir, a célula apical alongada divide-se no plano transversal originando uma célula colar (figura 17). A célula apical continua aumentando de volume e sofre outra divisão transversal originando mais uma célula colar passando o tricoma a apresentar quatro células, sendo uma basal, duas colares de tamanho menor e uma célula apical maior, alongada em forma de cone (figura 18). Nesta fase, todas as células do tricoma apresentam citoplasma denso, poucos vacúolos e núcleo esférico de posição central.
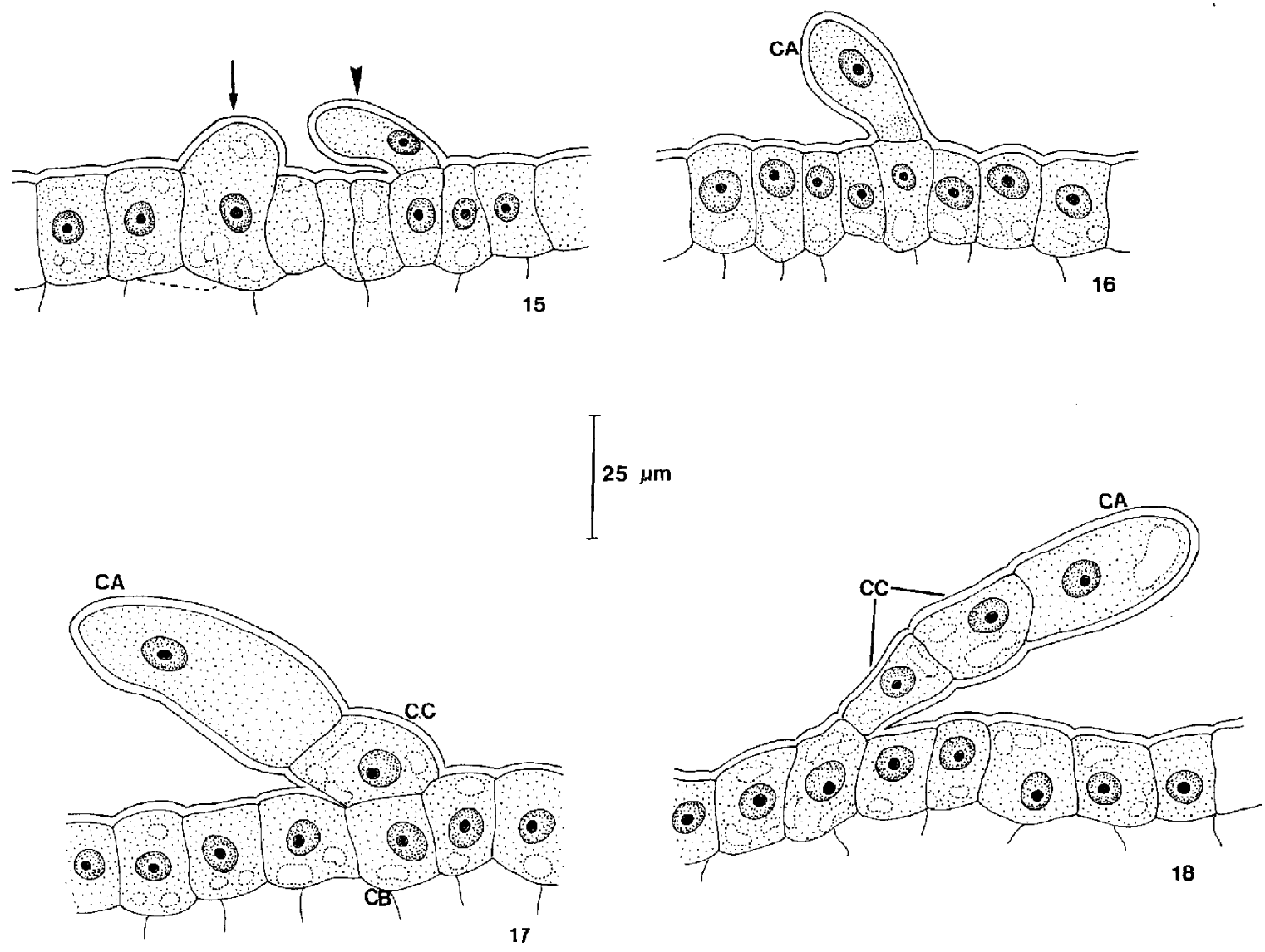

Figuras 15-18. Etapas sucessivas do desenvolvimento do tricoma saculiforme de P. regnellii var. regnellii. 15. Célula protodérmica papiliforme (seta) mostrando citoplasma denso com poucos vacúolos e núcleo central com nucléolo proeminente; a ponta de seta indica tricoma saculiforme bicelular com célula apical inclinada. 16. Tricoma saculiforme bicelular com célula apical (CA) mais volumosa. 17. Tricoma saculiforme tricelular mostrando célula apical (CA) com citoplasma denso e núcleo no pólo distal, célula colar (CC) com citoplasma denso, pequenos vacúolos e núcleo no pólo basal e célula basal (CB). 18. Tricoma saculiforme tetracelular mostrando célula apical (CA) com vesículas no pólo distal, duas células colares (CC) e uma célula basal. 
Os testes histoquímicos (tabela1) mostraram que a secreção produzida pelas glândulas peroladas presentes no limbo em desenvolvimento, consiste de lipídios, proteínas e, principalmente, de polissacarídeos. Estas três classes de substâncias foram detectadas no citoplasma da célula apical enquanto que, no espaço subcuticular e superfície da glândula, foram detectados unicamente polissacarídeos. Na folha adulta, a secreção presente no espaço subcuticular da glândula perolada consiste de lipídios (tabela 2).

Tabela 1. Testes histoquímicos evidenciando a natureza, a presença e a localização das substâncias nas glândulas peroladas de Piper regnellii var. regnellii (Piperaceae) - Limbo foliar em desenvolvimento.

\begin{tabular}{cccc}
\hline & \multicolumn{3}{c}{ Célula apical } \\
\cline { 2 - 4 } Substâncias & Citoplasma & $\begin{array}{c}\text { Espaço } \\
\text { subcuticular }\end{array}$ & Superfície \\
\hline Lipídios & + & - & - \\
Proteínas & + & - & - \\
Polissacarídeos & + & + & + \\
\hline
\end{tabular}

Resultado representado por: $(+)$ presente e (-) ausente

A secreção do tricoma saculiforme (tabela 3), tanto na folha em desenvolvimento quanto na folha adulta consiste de proteínas, polissacarídeos e, principalmente de lipídios. Estes foram evidenciados como gotículas no espaço subcuticular da célula apical e no citoplasma de todas as células do tricoma, sendo mais abundantes na célula apical. Proteínas foram detectadas no citoplasma das células colar e apical. Polissacarídeos foram detectados no citoplasma e na superfície da célula apical.

Tabela 2. Testes histoquímicos evidenciando a natureza, a presença e a localização das substâncias nas glândulas peroladas de Piper regnellii var. regnellii (Piperaceae) - Limbo foliar adulto.

\begin{tabular}{cccc}
\hline & \multicolumn{3}{c}{ Célula apical } \\
\cline { 2 - 4 } Substâncias & Citoplasma & $\begin{array}{c}\text { Espaço } \\
\text { subcuticular }\end{array}$ & Superfície \\
\hline Lipídios & + & + & - \\
Proteínas & - & - & - \\
Polissacarídeos & - & - & - \\
\hline
\end{tabular}

Resultado representado por: (+) presente e (-) ausente

\section{Discussão}

A denominação glândula perolada foi empregada por Solereder (1908) para designar tricomas secretores com célula apical esférica e reluzente, semelhante a uma pérola. Segundo este autor, as glândulas peroladas ocorrem em todos os órgãos aéreos de espécies de Piper, principalmente no caule e no pecíolo. Entretanto, em Piper regnellii var. regnellii observou-se que as glândulas peroladas ocorrem raramente no caule e pecíolo, sendo mais abundantes na face abaxial do limbo foliar jovem.

Em $P$. regnellii var. regnellii observou-se que estas glândulas são bicelulares, constituídas por uma célula basal e por uma célula apical conspícua cuja forma varia de semi-globóide a espatulada. A forma espatulada da célula apical é resultante da deposição progressiva de material parietal em seu pólo basal, formando um pedicelo, o qual permanece, temporariamente, preso à célula basal. Solereder (1908) relata que as glândulas peroladas presentes nas espécies de Piper são decíduas, podendo permanecer sob determinadas condições e correlacionam-se com corpos alimentares. Neste trabalho, foi observado que à medida que o limbo se expande, essas glândulas sofrem abscisão deixando uma cicatriz na superfície foliar. Contudo, chama atenção a permanência eventual dessas glândulas em folhas adultas, sendo freqüentemente visitadas e/ou transportadas por formigas. A interação observada entre formigas e glândulas peroladas pode ser um indicativo do provável papel dessas estruturas como fonte de alimentos, tal como referido por Rickson \& Risch (1984) para estruturas epidérmicas ocorrentes no pecíolo de Piper cenocladum.

A análise histoquímica das glândulas peroladas, revelou não somente a presença de substâncias lipídicas e de proteínas como referido por Solereder (1908) e Metcalfe \& Chalk (1950), mas, principalmente de polissacarídeos, sendo que a quantidade relativa destas substâncias difere nas glândulas peroladas presentes em folhas jovens e naquelas com o limbo distendido. A presença dessas três classes de substâncias na secreção já foi referida por Werker \& Fahn (1981) para os tricomas glandulares de Inula viscosa e por Machado et al. (1995) para os tricomas nectaríferos de Zeyheria digitalis. Variação na quantidade destas substâncias em função dos diferentes estágios de desenvolvimento, também foi observada para os tricomas glandulares de Inula viscosa (Werker 
Tabela 3. Testes histoquímicos evidenciando a natureza, a presença e a localização das substâncias nos tricomas saculiformes de Piper regnellii var. regnellii (Piperaceae).

\begin{tabular}{|c|c|c|c|c|}
\hline \multirow[b]{2}{*}{ Substâncias } & \multirow{2}{*}{$\begin{array}{l}\text { Célula colar } \\
\text { Citoplasma }\end{array}$} & \multicolumn{3}{|c|}{ Célula apical } \\
\hline & & Citoplasma & $\begin{array}{c}\text { Espaço } \\
\text { subcuticular }\end{array}$ & Superfície \\
\hline Lipídios & + & + & + & - \\
\hline Proteínas & + & + & - & - \\
\hline Polissacarídeos & - & + & - & + \\
\hline
\end{tabular}

\& Fahn 1981). Nas folhas jovens de Piper regnellii var. regnellii com o limbo ainda enrolado e protegido pela estípula, a secreção presente no espaço subcuticular e na superfície da glândula perolada é constituída unicamente de polissacarídeos. Esta secreção mucilaginosa, eliminada através do rompimento da cutícula distendida, recobre totalmente a superfície das folhas em desenvolvimento. De acordo com Fahn (1979), é comum a ocorrência de tricomas secretores de mucilagem em folhas e estípulas em desenvolvimento. Segundo Meyberg (1988), a mucilagem funciona na proteção contra a dessecação de estruturas foliares em desenvolvimento e na lubrificação entre superfícies de contato das folhas jovens enroladas. Estas funções podem ser também atribuídas à mucilagem presente na superfície das folhas jovens de $P$. regnellii var. regnellii. Já, nas folhas com limbo distendido, onde as glândulas peroladas estão expostas, a secreção presente no espaço subcuticular é constituída unicamente de lipídios.

A ocorrência de tricomas com célula apical saculiforme em $P$. regnellii var. regnellii é uma característica mencionada por Solereder (1908) para algumas espécies da família Piperaceae. Segundo esse autor, estes tricomas constituem-se de pequenas glândulas de origem epidérmica com pedicelo e célula apical saculiforme, esférica ou hemi-esférica. Em $P$. regnellii var. regnellii esses tricomas apresentam-se com 3-4 células, cuja célula apical é saculiforme. Os tricomas saculiformes também se originam na protoderme do primórdio foliar e atingem sua maturidade nas folhas jovens, enroladas e protegidas pela estípula. Estes tricomas não sofrem abscisão, senescendo nas folhas, característica já mencionada para tricomas secretores de substâncias lipofílicas (Fahn 1979, Rodriguez et al. 1984).
A suberização observada nas paredes tangenciais da célula colar dos tricomas saculiformes, segundo Fahn (1979), é um fenômeno comum em tricomas secretores de substâncias lipídicas. Tal especialização parece estar relacionada com o controle do fluxo do material secretado no apoplasto (Schnepf 1972, Dell \& Mccomb 1977, Fahn 1979).

De acordo com Solereder (1908), os tricomas saculiformes não produzem secreção ou se esta ocorrer, seria produzida em pequena quantidade apenas na célula apical. Entretanto, em $P$. regnellii verificou-se, através dos testes histoquímicos, a presença de proteínas, polissacarídeos e principalmente gotas de lipídios em todas as células do tricoma. Contudo, acúmulo de secreção no espaço subcuticular foi detectado unicamente na célula apical, não sendo observada ruptura da cutícula em nenhum dos estágios analisados. A mucilagem presente na superfície destes tricomas provém da secreção liberada pelas glândulas peroladas.

Existem evidências de que gotas lipídicas acumuladas no espaço subcuticular dos tricomas secretores representam óleos voláteis (Fahn 1979, Rodriguez et al. 1984), e sua liberação pode ocorrer via cutícula íntegra ou através de poros na mesma, conforme relatado por Schnepf (1969) e Amelunxen (1964).

A presença de óleo essencial contendo terpenos identificados como cariofileno, limoneno, geraniol e linalol em folhas de $P$. regnellii var. regnellii foi detectada por Salatino \& Silva (1975) em idioblastos e células do parênquima clorofiliano. Segundo esses autores, no material botânico analisado não havia tricomas secretores. Os dados do presente trabalho sugerem que a ausência destas estruturas pode estar relacionada com a fase de desenvolvimento foliar utilizada pelos referidos autores. Provavelmen- 
te, os lipídios presentes nos tricomas de $P$. regnellii var. regnellii constituam-se de terpenos, contudo, não se pode afirmar que sejam os mesmos detectados por Salatino \& Silva (1975).

\section{Referências bibliográficas}

ALENCAR, R., LIMA, R.A., CORRÊA, R.G.C., GOTTLIEB, O.R., MARX, M.C., SILVA, M.L., MAIA, J.G.S., MAGALHÃES, M.T. \& ASSUMPÇÃO, R.M. 1971. Óleos essenciais de plantas brasileiras. Acta Amazônica 1:41-43.

AMELUNXEN, F. 1964. Elektronenmikroskopische untersuchungen an den drusenhaaren von Mentha piperita. L. Planta Medica 12:121-139.

DELL, B. \& MCCOMB, A.J. 1977. Glandular hair formation and resin secretion in Eremophila fraseri F. Meull (Myoporaceae). Protoplasma 92:71-86.

DI STASI, L.C. 1987. Triagem farmacológica de plantas medicinais com atividade analgésica. Dissertação de mestrado. Escola Paulista de Medicina, São Paulo.

FAHN, A. 1979. Secretory tissues in plants. Academic Press, London.

JENSEN, W.A. 1962. Botanical histochemistry: principle and pratice. W.H. Freeman, San Francisco.

JOHANSEN, D.A. 1940. Plant microtechnique. McGraw-Hill, New York.

KARNOVSKY, M.J. 1965 A formaldehyde-glutaraldehyde fixative of high osmolality for use in electron microscopy. J. Cell. Biol. 27:137-38.

MACHADO, S.M.F., MILITÃO, J.S.L.T., FACUNDO, A., RIBEIRO, A., MORAIS, S.M. \& MACHADO, M.I.L 1994. Leaf oils of two Brazilian Piper species: Piper arboreum Aublet var. latifolium (C.DC.) Yuncker and Piper hispidum Sw. J. Essen. Oil Res. 6:643-4.
MACHADO, S.R., GREGORIO, E.A., YANAGIZAWA,Y. \& CARMELLO, S.M. 1995. Ultrastructural aspects of the peltate glandular trichomes of the gynoecium in Zeyheria digitalis (Vell.) Hoehne (Bignoniaceae). Revta brasil. Bot. 18:197-205.

MAIA, J.G., SILVA, M.L., LUZ, A.I.R., ZOGHBI, M.G.B. \& RAMOS, L.S. 1992. Espécies de Piper da Amazônia ricas em safrol. Química Nova. São Paulo 10:200-204.

METCALFE, C.R \& CHALK, L. 1950. Anatomy of the dicotyledons. Clarendon, Oxford.

MEYBERG, M. 1988. Cytochemistry and ultrastructure of the mucilage secreting trichomes of Nymphoides peltata (Menyanthaceae). Ann. Bot. 62:537-548.

O'BRIEN, T.P., FEDER, N. \& MC CULLY, M.E.1964 Polychromatic staining of plant cell wall by toluidine blue. Protoplasma 59:39-52.

RICKSON, F.R. \& RISCH, S.J. 1984. Anatomical and ultrastructural aspects of the ant-food cell of Piper cenocladum C. DC. (Piperaceae). Am. J. Bot. 71:1268-1274.

ROBARDS, A.W. 1978. An introduction to techniques for scanning electron microscopy of plant cells. In Electron microscopy and cytochemistry of plant cells. (J.L. Hall, ed.), Elsevier, New York.

RODRIGUEZ, E., HEALEY, L. \& MEHTA, I. 1984. Biology and chemistry of plant trichomes. Plenum, New York.

SALATINO, A. \& SILVA, J.B. 1975. Anatomia e óleo essencial das folhas de Piper regnellii (MIQ.) C. DC. var. regnellii. Bolm. Botânica Univ. S. Paulo 3:95-106.

SCHNEPF, E. 1969. Sekretion und Exkretion bei Pflanzen. Protoplasmatol Hanb Protoplasmaforsch. 8:1-181.

SCHNEPF, E. 1972. Tubulares endoplasmatisches reticulum in Drusen mit lipophilen Ausscheidungen von Ficus, Ledum and Salvia. Biochem. Physiol. Pflanz. (BBP) 163:113-25.

SOLEREDER, H. 1908. Systematic anatomy of dicotyledons. Clarendon, Oxford.

WERKER, E. \& FAHN, A. 1981. Secretory hairs of Inula viscosa L. Ait - development, ultrastructure and secretion. Bot. Gaz. 142:461-476. 